\title{
Development Features of Supercritical (Ultra-Supercritical) Technology in the World and Experiences We Can Learn
}

\author{
Weixiang Ye \\ School of Energy Power and Mechanical Engineering, North China Electric Power University, Beijing, China \\ Email: 2258092448@qq.com
}

Received 17 May 2016; accepted 10 June 2016; published 13 June 2016

Copyright (C) 2016 by authors and Scientific Research Publishing Inc.

This work is licensed under the Creative Commons Attribution International License (CC BY). http://creativecommons.org/licenses/by/4.0/

(c) (i) Open Access

\begin{abstract}
The development and technical characteristics in different stages of supercritical (ultra-Supercritical) technology abroad are introduced in this paper. At the same time, according to the development trend of supercritical (ultra-supercritical) technology, the corresponding revelations are given in this paper. That is: It is an inevitable choice to develop supercritical (ultra-supercritical) technology if we want to improve the thermal efficiency and heat efficiency.
\end{abstract}

Keywords

Supercritical (Ultra-Supercritical) Technology, The Thermal Efficiency, Heat Efficiency

\section{The Introduction}

Supercritical unit refers to the steam pressure ranging 24 - $27 \mathrm{MPa}$ in general. Ultra supercritical unit refers to the steam pressure over $27 \mathrm{MPa}$ or steam temperature above $593^{\circ} \mathrm{C}$. According to the basic knowledge of engineering thermodynamics, it is effective for the simple thermodynamic cycle to improve thermal efficiency by increasing the initial pressure or temperature. This is also applicable to actual cycles [1].

For thermal power units, with the improvement of steam parameter, the unit efficiency is rising, net coal consumption rate is decreasing gradually, and emissions of pollutants are also reduced, which have significant effect on improving the economic benefits [2].

\section{The Introduction of Development of the Supercritical (Ultra-Supercritical) Boiler Technology in the World}

The development history of the power generation technology of supercritical (ultra-supercritical) has been more 
than half a century. Since the 1950s, represented by the United States, Japan and the European Union, the world began to research and develop power generation technology of supercritical (ultra-supercritical). This article gives a brief discussion on supercritical (ultra-supercritical) technology of The United States, Japan and the European Union respectively.

\subsection{The United State}

The United States is the earliest country to develop technology of supercritical power generation. In the early 1950s, it set about to research supercritical and ultra-supercritical technology. In 1957, the first ultra-supercritical unit of world $\left(125 \mathrm{MW}, 31 \mathrm{MPa} / 621^{\circ} \mathrm{C} / 566^{\circ} \mathrm{C} / 566^{\circ} \mathrm{C}\right.$ ) was put into operation in Philo power plant. In 1958 , the second ultra-supercritical unit $\left(325 \mathrm{MW}, 36.5 \mathrm{MPa} / 654^{\circ} \mathrm{C} / 566^{\circ} \mathrm{C} / 566^{\circ} \mathrm{C}\right)$ with the largest capacity and highest parameters in the world was put into operation in the Ed-dy stone power plant, and the boiler of this unit was designed and manufactured by CE Company of the United States.

Because the thermal efficiency of supercritical unit is significantly higher than the subcritical unit, in the mid-1960s, more than half of the new-built units were supercritical unit. During the 10 years from 1967 to 1976 , 118 sets of supercritical units were put into operation, and the largest single machine capacity was 1300 MW. Starting in the 70s, the order of supercritical units was reduced. During the period of 1980-1989, only 7 supercritical units were put into operation.

In order to improve the availability ratio of unit, supercritical units later adopted the parameters with 24.1 $\mathrm{MPa} / 538^{\circ} \mathrm{C} / 538^{\circ} \mathrm{C}$ (individual with $541^{\circ} \mathrm{C}-543^{\circ} \mathrm{C}$ ), while parameters of the second reheat steam with $552^{\circ} \mathrm{C} /$ $566^{\circ} \mathrm{C}$. And they were improved constantly. These steam parameters remained more than 20 years.

In 1992, the 107 thermal power units in service of $800 \mathrm{MW}$ and above in The United States were all supercritical units. Among them the largest single machine capacity is $1300 \mathrm{MW}$. In 1999, the US department of energy put forward the Vision 21 plan [3] to develop advanced power generation technology. At the same time, for ultra-supercritical technology, Ultra-supercritical thermal power generating units $\left(35 \mathrm{MPa} / 760^{\circ} \mathrm{C} / 760^{\circ} \mathrm{C}\right.$ / $760^{\circ} \mathrm{C}$ ) were mainly developed, which make its thermal efficiency above 55\%, and the pollution emissions lower than the subcritical units by $30 \%$ [4].

In the 21st century, the GE Company for Japan produced USC units with steam parameters of $26.6 \mathrm{MPa} /$ $577^{\circ} \mathrm{C} / 600^{\circ} \mathrm{C}$ and $25 \mathrm{MPa} / 600^{\circ} \mathrm{C} / 610^{\circ} \mathrm{C}$. Starting in 2002 , the United States set the working parameters of the units to a higher value, namely $37.9 \mathrm{MPa} / 723^{\circ} \mathrm{C} / 760^{\circ} \mathrm{C}$, with the goal to a temperature of $760^{\circ} \mathrm{C}$ and the efficiency increased by $50 \%$ in 2020 [5].

\subsection{Japan}

Japan developed supercritical technology by means of imitation, innovation and introduction of advanced technology.

From 1967, when Japan first imported the supercritical units (660 MW, $\left.24.12 \mathrm{MPa}, 538^{\circ} \mathrm{C} / 566^{\circ} \mathrm{C}\right)$ from America, to the end of 1985, there were 77 sets of supercritical units put into operation, including many 700 MW and 1000 MW supercritical pressure units.

Because improving steam parameters can further improve the thermal efficiency of the unit, the Japanese made a plan of developing ultra-supercritical units on the basis of mature supercritical units $\left(24.1 \mathrm{MPa} / 538^{\circ} \mathrm{C} /\right.$ $\left.566^{\circ} \mathrm{C}\right)$. Among them, the units $\left(700 \mathrm{MW}, 31.1 \mathrm{MPa} / 566^{\circ} \mathrm{C} / 566^{\circ} \mathrm{C} / 566^{\circ} \mathrm{C}\right)$ which designed by Mitsubishi, were put into operation in the chuanyue power plant respectively in 1989 and 1989 . Moreover they run in good condition, and the availability ratio also reached a high level.

In the 1990s, the new units put into operation were almost supercritical or ultra-supercritical units.

In 2000, the two supercritical units designed by IHI were put into operation at Orange bay power plant (1050 $\left.\mathrm{MW}, 25.5 \mathrm{MPa} / 600^{\circ} \mathrm{C} / 610^{\circ} \mathrm{C}\right)$. A plan of developing ultra-supercritical units $\left(34.5 \mathrm{MPa} / 620^{\circ} \mathrm{C} / 650^{\circ} \mathrm{C}\right)$ fermented its mind. In August 2008, A - USC project was startup and it was expected to increase the thermal efficiency to $46 \%$ with the working parameters valuing to $35 \mathrm{MPa} / 700^{\circ} \mathrm{C} / 720^{\circ} \mathrm{C} / 720^{\circ} \mathrm{C}$. What is more, a demonstration power plant will be established in 2020, and thermal efficiency will be improved to $48 \%$ further [6].

In a word, Japan started to research ultra-supercritical units relatively late, but soon after, the transition from imitation to applying their own scientific research happened soon, and it set up its own test bed at the same time. The development of supercritical (ultra-supercritical) technology was rapid with great the outcome. 


\subsection{The European Union}

Germany is one of the earliest countries to research and manufacture supercritical units in the world. In 1956 an ultra-supercritical unit $\left(88 \mathrm{MW}, 34 \mathrm{MPa} / 610^{\circ} \mathrm{C} / 610^{\circ} \mathrm{C} / 570^{\circ} \mathrm{C}\right.$ ) was put into operation. In 1972 , a supercritical unit of $430 \mathrm{MW}$ (parameters of $24.5 \mathrm{MPa} / 535^{\circ} \mathrm{C} / 535^{\circ} \mathrm{C}$ ) was put into operation. Andin 1979, a second reheat supercritical unit of $475 \mathrm{MW}$ (parameters of $25.5 \mathrm{MPa} / 530^{\circ} \mathrm{C} / 540^{\circ} \mathrm{C} / 530^{\circ} \mathrm{C}$ ) was put into operation.

With the breakthrough of materials technology in the early 1990s, a batch of new materials suitable for $600^{\circ} \mathrm{C}$ grade were put into practical application, driving the design temperature of the supercritical unit to jump from $540^{\circ} \mathrm{C}-566^{\circ} \mathrm{C}$ to $580^{\circ} \mathrm{C}-610^{\circ} \mathrm{C}$ (ultra-supercritical temperature) [7]. At the same time, the single machine capacity of ultra-supercritical also stands up the steps of the 1000 MW steadily. Some representative of supercritical units in German was: the unit of 500 MW put into operation in Staudinger power plant in August 1992 (parameters of $26.2 \mathrm{MPa} / 545^{\circ} \mathrm{C} / 562^{\circ} \mathrm{C}$ ); the supercritical unit put into operation in Lippen - dorp in 1999 (26.7 $\left.\mathrm{MPa} / 554^{\circ} \mathrm{C} / 593^{\circ} \mathrm{C}\right)[8]$.

The AD700 plan was put forward by The European Union in 1998. (AD700 plan of the European Union).Its main goal is to develop ultra-supercritical power generation units with the steam parameters of $37.5 \mathrm{MPa}, 700^{\circ} \mathrm{C}$ (main steam temperature) $/ 720^{\circ} \mathrm{C}$ (reheat steam temperature), which can increase the net efficiency of generating units to $52 \%$ - 55\%, and minimize the fuel consumption. in this way, it is easy to reduce emissions of $\mathrm{CO}_{2}$.

The latest achievements of Landmark project of reheat ultra-supercritical technology in European is the ultrasupercritical project of $2 \times 100 \mathrm{MW}$ in Neurath power plant, which started to construct in 2006, and was put into production in 2012.

\section{Conclusions and Revelations}

In order to improve the thermal efficiency, it is an all-important choice to increase the parameters of steam pressure and temperature. Through decades of development, the supercritical (ultra-supercritical) technology has lots of advantages. For example, the technology is mature and reliable, and it has high thermal efficiency, low cost and less pollution. Ultra supercritical units can be comparable with subcritical unit in the aspects of energy availability and load operation, High-capacity ultra-supercritical unit has higher thermal efficiency than supercritical unit.

Technology of high-capacity supercritical (ultra-supercritical) which is mature will be the main direction of power generation technology of clean coal in the world, and it is also the most effective way to solve the power shortage, low efficiency and serious environmental pollution problems. It is urgent to strengthen the research on the supercritical and ultra-supercritical technology, which has great significant meaning to grasp the ultrasupercritical unit characteristics and optimizing operation.

\section{References}

[1] Meng, X., Gao, J.R., Yu, N. and Liu, Y. (2006) Research of Calculation Method for the Actual Cycle Thermal Efficiency of a Steam Turbine. Energy Conservation Technology, 24, 133-135.

[2] Chen, X.K. (2002) The Development of Supercritical Boiler Technology. Electrical Equipment, 3, 19-24.

[3] Luo, Y.F., Du, M.H. and Li, W.H. (2005) The Summary of Research and Promotion Plan on America's Future Clean Coal Technology. The Branch Institute of Coal Chemical Industry Research in Beijing.

[4] Xu, M.T., Yuan, Y.C., Chen, G.J. and Shao, G.Z. (2003) Developmental Trend of Super Large Capacity and Ultra Supercritical Boilers. Power Engineering, 23, 2363-2369.

[5] Li, R. and Guan, L. (2009) The Development and Enlightenment of Ultra-Supercritical Technology in the World. China Power Enterprise Management, No. 4, 40-41.

[6] Chi, C.Y., Yu, H.Y. and Xie, X.S. (2013) Critical High Temperature Materials for $700^{\circ}$ CA-USC Power Plants. The World Steel, No. 2, 42-63.

[7] Feng, W.Z. (2008) Development Features of Ultra-Supercritical Units in Europe and Experiences We Can Learn. East China Electric Power, 36, 127-131.

[8] Xiong, W.L., Huang, W. and Peng, M. (2008) Characteristics and Development Direction of Supercritical Boiler Technology. Hu Nan Electric Power, 28, 58-62. 